\title{
WIZERUNEK PAPIEŻA PIUSA XII W PROPAGANDZIE KOMUNISTYCZNEJ W POLSCE W LATACH 1945-1958
}

\author{
Marcin Sanak \\ Uniwersytet Jagielloński w Krakowie
}

\begin{abstract}
THE IMAGE OF POPE PIUS XII IN THE COMMUNIST PROPAGANDA IN POLAND IN THE YEARS 1945-1958
\end{abstract}

After World War II, Pius XII, Pope in the years 1939-1958, became a victim of Communist propaganda in the countries behind the Iron Curtain, including Poland. The head of the Catholic Church was defamed in speech, in writing and using images. This article focuses on the issue of the image of Pius XII emerging from Polish newspapers, books and brochures in 1945-1958. It presents a synthetic image of the Pope created by the authors of publications which could potentially reach each and every Pole. The propaganda depicted the Bishop of Rome as a fascist, a Nazi, an anti-communist, a supporter of "Anglo-American imperialism," a warmonger, "the Atlantic Pope," a capitalist, a nepotist, an enemy of workers and peasants, a Germanophile, an anti-Polish revisionist, and a reactionary in matters of science, faith and morality.

Key words: Pius XII, pope, antipapal propaganda, communist propaganda, Vatican City, People's Poland.

Słowa kluczowe: Pius XII, papież, propaganda antypapieska, propaganda komunistyczna, Watykan, Polska Ludowa.

Pius XII - papież w latach 1939-1958 - zaliczany jest do grupy najbardziej kontrowersyjnych postaci w historii XX wieku. Od kilku dekad trwa spór historyków odnośnie do oceny działalności przywódcy Kościoła katolickiego w czasie II wojny światowej. Większość zachodnich badaczy za jego początek postrzega wystawioną w 1963 roku sztukę teatralną Rolfa Hochhutha Namiestnik. Tragedia chrześcijańska. Niemal całkowitym milczeniem pomija się za to fakt, że w krajach za żelazną kurtyną Eugenio Pacelli stał się negatywnym bohaterem komunistycznej propagandy 
już w latach 40. i 50. XX wieku. Po zakończeniu II wojny światowej, gdy nastąpił podział na dwa wrogie sobie bloki państw w stanie zimnej wojny, w ramach walki z zachodnim „obozem kapitalistycznym” i religią postanowiono zaatakować Stolicę Apostolską i Piusa XII. Wpływ na negatywną postawę wobec papieża miała także jego mocno antykomunistyczna postawa. Pacellego zaczęto postponować w Związku Radzieckim, a następnie w innych krajach Europy Wschodniej, także w Polsce.

Propaganda antypapieska nad Wisłą - stanowiąca ważne ogniwo szerszej propagandy antykościelnej - posiadała jednak swój wyjątkowy, odrębny charakter. Wynikało to przede wszystkim z faktu, że Polacy byli najbardziej katolickim społeczeństwem wśród państw za żelazną kurtyną. Komuniści zdawali sobie sprawę, że zaprowadzenie i utrwalenie socjalizmu nad Wisłą będzie możliwe jedynie wówczas, gdy osłabione zostaną autorytet i siła oddziaływania Kościoła, którego najwyższym zwierzchnikiem był papież. Potencjalnemu powodzeniu antyreligijnych kampanii mógł sprzyjać fakt, że Pacelli był krytykowany przez część podziemia (głównie członków organizacji lewicowych) za bierność i milczenie wobec okrucieństw faszyzmu już w czasie II wojny światowej. Po jej zakończeniu Pius XII - hierarcha żyjący z dala od polskich granic, były nuncjusz apostolski w Monachium i Berlinie, antykomunista, domniemany germanofil i przyjaciel „wypędzonych” z tzw. Ziem Odzyskanych Niemców, rzekomy sojusznik zachodnich, „imperialistycznych” polityków - wydawał się postacią wręcz predestynowaną do stania się ofiarą nagonki.

W rodzimej historiografii brakuje pozycji poświęconej analizie antypapieskiej propagandy komunistycznej nad Wisłą ${ }^{1}$. Niniejszy artykuł skupia się tylko na jednym

1 Jak dotąd nie ukazała się drukiem publikacja omawiająca antypapieską propagandę okresu stalinowskiego w sposób całościowy. Zagadnienie to poruszyli m.in.: B. Cywiński, Ogniem próbowane. Z dziejów najnowszych Kościoła katolickiego w Europie Środkowo-Wschodniej, t. 2: „... i was prześladować będq", Warszawa 1994, s. 50-52, 371-373; A. Dudek, Państwo i Kościót w Polsce w latach 1945-1970, Kraków 1995, s. 15-17; J. Żaryn, Kościót a władza w Polsce (1945-1950), Warszawa 1997, s. 179-183, 230; J. Ste faniak, Polityka władz państwowych PRL wobec prasy katolickiej w latach 1945-1953, Lublin 1998, s. 52-53, 56, 74-77, 80-81, 83, 88-89, 110 i nast.; R. Gryz, Państwo a Kościót w Polsce 1945-1956. Na przykładzie województwa kieleckiego, Kraków 1999, s. 199-200, 210-212; M. Ordyłowski, Polityka lokalnych władz PRL wobec Kościoła katolickiego na Dolnym Ślasku w latach 1945-1979 [w:] Stefan kardynat Wyszyński wobec Ziem Zachodnich i Pótnocnych oraz stosunków polsko-niemieckich. W 100-lecie urodzin Prymasa Tysiaclecia, red. T. Dzwonkowski, Cz. Os sęowski, Warszawa-Poznań-Zielona Góra 2001, s. 99-101, 105-107; Ł. Kamiński, Antykościelna kampania propagandowa na Dolnym Śląsku w 1949 r. (po ekskomunice członków partii marksistowskiej) [w:] Propaganda antykościelna w Polsce w latach 1945-1978, red. S. Dąbrow ski, B. Rogowska, Wrocław 2001, s. 126-137; W. Jurkiewicz, Antykościelna propaganda na łamach miesięcznika ,Wiedza i Życie” w latach 1950-1956 [w:] Propaganda antykościelna w Polsce..., s. 67-70; N. Wój to wicz, Walka $o$, kulturę świecka” w pracach pierwszego przewodniczacego Stowarzyszenia Ateistów $i$ Wolnomyślicieli [w:] Propaganda antykościelna w Polsce..., s. 104 i nast.; J. Sikorski, Władza a Kościót na Ziemi Lubuskiej w latach 1945-1956, „Rocznik Lubuski” 2005, t. 31, cz. 2, s. 97-100; Z. Zieliński, Pius XII. Historiografia zaangażowana [w:] Pius XII. Papież w epoce totalitaryzmów. Historiografia i polityka, red. M. Kornat, Kraków 2010, s. 23-24; G. Kucharczyk, Obraz pontyfikatu Piusa XII w prasie polskiej (w Kraju i na emigracji po 1945 r.). Próba zarysu [w:] Pius XII. Papież w epoce totalitaryzmów..., s. 251-257; A. Dziurok, Kruchtoizacja. Polityka władz partyjno-państwowych wobec Kościoła katolickiego w latach 1945-1956 w województwie ślaskim/katowickim, Katowice 2012, s. 480-481, 512. W 2004 r. w Instytucie Historycznym Uniwersytetu Wrocławskiego obroniona została nieopublikowana 
z jej aspektów: obrazie Piusa XII wyłaniającym się z polskiej prasy, książek i broszur $\mathrm{z}$ lat 1945-1958. Tym samym stawia sobie za cel przedstawienie w sposób całościowy, a zarazem syntetyczny wizerunku biskupa Rzymu kreowanego przez autorów publikacji, które potencjalnie mogły znaleźć się w rękach niemal każdego przeciętnego Polaka. Spośród najważniejszych antypapieskich książek i broszur, które poddano analizie, należy wymienić prace: Watykan a Polska Stanisława Krasowskiego ${ }^{2}$, Polityka Watykanu wobec Polski Władysława Bieńkowskiego³, Między Watykanem a Polska Edwarda Ligockiego ${ }^{4}$, Watykan $i$ Wrzesień Stefana Arskiego (używającego pseudonimu Roman Warecki) ${ }^{5}$, Watykan czy Polska? Józefa Sikory ${ }^{6}$, Papież Pius XII $w$ świetle wlasnych przemówień i listów z lat 1945-19517 oraz 1000 lat zatargów z papieżami $^{8}$ Andrzeja Nowickiego. W przypadku czasopism kwerendę przeprowadzono na podstawie tytułów o zróżnicowanym profilu tematycznym i częstotliwości ukazywania się, takich jak: „Głos Ludu”, „Trybuna Ludu”, „Trybuna Robotnicza”, „Polska Zbrojna”, „Żołnierz Wolności”, „Przekrój”, „Polityka”, „Po Prostu”, „Sztandar Młodych”, „Przyjaciółka”, „Polska i Świat Współczesny”, „Świat i Polska”, „Świat i Polska - Przegląd Międzynarodowy”, „Przegląd Historyczny”, „Myśl Filozoficzna”, „Szpilki”, „Mucha”, „Głos Wolnych” i „Argumenty”. Opisując wizerunek papieża kreowany przez komunistów - ze względu na niewielką objętość artykułu i jego syntetyczny charakter - ograniczono się do podawania w przypisach danych bibliograficznych źródeł jedynie w przypadku zamieszczonych w tekście głównym cytatów, a także bezpośredniego nawiązywania do określonych publikacji.

W pierwszej kolejności warto - na podstawie wspomnianych materiałów źródłowych - przyjrzeć się pokrótce dynamice i narzędziom antypapieskiej propagandy. Treści wymierzone w Piusa XII pojawiały się w przestrzeni publicznej już w latach 1945-1947, m.in. po przyjęciu przez rząd w Warszawie dnia 12 września 1945 roku uchwały stwierdzającej nieobowiązywanie konkordatu ze Stolicą Apostolską. Jednak pierwsza wielka kampania „,antypacelliańska” została rozpętana z inicjatywy najwyższych władz partyjno-państwowych w 1948 roku, po liście papieża do biskupów niemieckich z 1 marca. W dokumencie tym Pacelli zdecydowanie zawyżył liczbę niemieckich przesiedleńców z Ziem Zachodnich i Północnych (o ok. 9 milionów) oraz zasugerował „cofnięcie, co zostało dokonane”, co zinterpretowano jako postulat

praca doktorska Andrzeja Nowaka pt. Propaganda antypapieska w Polsce w latach 1945-1956, napisana pod kierunkiem prof. dr. hab. Jerzego Kazimierza Pietrzaka. Rozprawa bazowała przede wszystkim na źródłach prasowych, a w mniejszym stopniu na materiałach archiwalnych. Niniejszy artykuł powstał na podstawie pracy magisterskiej autora pt. Papież Pius XII w propagandzie komunistycznej w Polsce w latach 1945-1958, napisanej pod kierunkiem dr. hab. Zdzisława Zblewskiego w Instytucie Historii Uniwersytetu Jagiellońskiego i obronionej w 2016 r.

2 S. Krasowski, Watykan a Polska, Warszawa 1949.

W. Bieńkowski, Polityka Watykanu wobec Polski, Warszawa 1950.

4 E. Ligocki, Między Watykanem a Polska, Warszawa 1949.

5 R. Warecki [S. Arski], Watykan i Wrzesień, Warszawa 1958.

6 J. Sikora, Watykan czy Polska?, Warszawa 1950.

7 A. Nowicki, Papież Pius XII w świetle własnych przemówień i listów z lat 1945-1951, Warszawa 1952.

8 Idem, 1000 lat zatargów z papieżami, Warszawa 1950. 
rewizji granic na Odrze i Nysie Łużyckiej ${ }^{9}$. Druga akcja antypapieska o ogólnokrajowym zasięgu miała miejsce $\mathrm{w}$ drugiej połowie 1949 roku, po ogłoszeniu treści dekretu Świętego Oficjum z 1 lipca, grożącego ekskomuniką katolikom przynależącym do partii komunistycznych oraz czynnie wspierającym ideologię komunistyczną ${ }^{10}$. Obie kampanie wymierzone w Piusa XII stanowiły część szerszej ofensywy antykościelnej władz, które zerwały z dotychczasową taktyką tworzenia pozorów współpracy i porozumienia z katolicką wspólnotą. Aż do roku 1953 propaganda antypapieska i antywatykańska charakteryzowała się dużą częstotliwością i zjadliwością. W tym okresie szczególnie często komentowano encykliki, publiczne wystąpienia, audiencje i ważne decyzje podejmowane przez Pacellego, a także pochylano się nad jego działalnością przed i w czasie II wojny światowej. Mnożące się ataki na papieża zdecydowanie osłabły w 1954 roku, jednak nie wygasły aż do jego śmierci w roku 1958.

Piusa XII deprecjonowano przy użyciu słowa mówionego, słowa pisanego (drukowanego) oraz obrazu. Jego postać przewijała się w przemówieniach przedstawicieli najwyższych władz państwowych, liderów Polskiej Partii Robotniczej, a następnie Polskiej Zjednoczonej Partii Robotniczej i partii sprzymierzonych. Antypapieskie przemówienia wygłaszano podczas plenów Komitetu Centralnego PZPR, posiedzeń Sejmu, kongresów organizacji społecznych, zjazdów związków zawodowych, ulicznych wieców protestacyjnych oraz akademii świątecznych i rocznicowych. W całym kraju odbywały się posiedzenia plenarne wojewódzkich, powiatowych, miejskich i gminnych rad narodowych, wiece i masówki w zakładach pracy, zebrania gromadzkie oraz spotkania członków instytucji państwowych i organizacji społecznych. Na ich przebieg składały się zazwyczaj: jedno lub kilka przemówień, przyjęcie rezolucji protestacyjnych przeciwko polityce Pacellego, a niekiedy także uchwalenie zbiorowych zobowiązań. W całym kraju antypapieskie referaty wygłaszali także członkowie kół wolnomyślicielskich.

Niezwykle ważnym narzędziem propagandowym władz stały się książki, broszury i artykuły o charakterze „,naukowym”, ,informacyjnym” i publicystycznym, zawierające treści wymierzone w biskupa Rzymu. Ich autorzy dążyli do nagromadzenia $w$ tekście pejoratywnych sformułowań odnoszących się do papieża i Watykanu. Jako wyraz woli Piusa XII interpretowano bowiem każde posunięcie Stolicy Apostolskiej, podkreślając, że od 1944 roku Pacelli bezpośrednio kierował Sekretariatem Stanu. W prasie ogólnopolskiej i regionalnej ukazywały się udzielane redaktorom komentarze oraz listy przysyłane jakoby przez „zwykłych obywateli”, w których piętnowano rzekome czyny i poglądy Piusa XII. Z kolei w czasopismach i wydawnictwach zbiorowych zamieszczano krótkie utwory satyryczne (m.in. fraszki, aforyzmy, kalambury i gry słów, dialogi, listy satyryczne, bajki, piosenki i dowcipy), pełne krytycznych przytyków i kpin z biskupa Rzymu. Narzędziami dyskredytacji estetycznej Piusa XII stały się ponadto karykatury, publikowane w gazetach i pracach zbiorowych. Swój antypapieski wydźwięk posiadały nie tylko dzięki ukazywaniu sylwetki Pacellego, ale także poprzez posłużenie się symbolami

\footnotetext{
J. Żaryn, Kościót a władza w Polsce..., s. 179-191.

10 Ibidem, s. 227-231; R. Gryz, op. cit., s. 210-212; Ł. Kamiński, op. cit., s. 126-137.
} 
i atrybutami Stolicy Apostolskiej oraz papieża, jak również dokumentami, które należało jednoznacznie łączyć z jego osobą. Swoją rolę odgrywały ponadto inne rysunki oraz fotografie opatrzone tytułami i podpisami wymierzonymi w Piusa XII. Część broszur, artykułów, wierszy i karykatur wydano poza Polską, np. w Związku Socjalistycznych Republik Radzieckich i Rumunii. Dzieła, po przetłumaczeniu z języków obcych, służyły jednak „sprawie” w tym samym stopniu, co prace rodzimych publicystów i satyryków. Antypapieskiej propagandzie przewodził przede wszystkim główny organ partii komunistycznej - „Głos Ludu”, a następnie „Trybuna Ludu". Najostrzejsze ataki na Pacellego przypuszczano jednak na łamach czasopism ateistycznych i wolnomyślicielskich, takich jak „Głos Wolnych” czy „Argumenty”, a w drugim rzędzie - satyrycznych, np. „Szpilek” i „Muchy”. Niektóre tytuły włączały się $\mathrm{w}$ antypapieską propagandę doraźnie i tylko w określonych momentach - przede wszystkim podczas trwania wielkich kampanii antykościelnych i ,antypacelliańskich". Stosunkowa jednolitość i powtarzalność zarzutów stawianych biskupowi Rzymu w prasie świadczy o „ręcznym” sterowaniu redakcjami przez najwyższe władze partyjne ${ }^{11}$.

Piusa XII portretowano najczęściej jako „osobistość zdecydowaną, konsekwentną i z uporem realizującą cele swej polityki" "2, postać zimną i wyrachowaną, bezwzględnie kalkulującą zyski i straty Kościoła w przypadku wypowiadania konkretnych słów lub dokonywania określonych czynów. Papieżowi najczęściej zarzucano kłamstwo, milczenie wobec niesprawiedliwości, zaniechanie działania, instrumentalne traktowanie wiernych, ale przede wszystkim uprawianie politykierstwa - pomimo zapewnień o bezstronności. Piusa XII przedstawiano jako faszystę, hitlerowca, antykomunistę, zwolennika ,anglo-amerykańskiego imperializmu”, podżegacza wojennego, „papieża atlantyckiego”, kapitalistę, nepotystę, wroga robotników i chłopów, germanofila, antypolskiego rewizjonistę, a także reakcjonistę w zakresie nauki, wiary i moralności. Warto przyjrzeć się bliżej zarzutom związanym z powyższymi sformułowaniami.

Piusa XII oskarżano niezwykle często o wspieranie faszyzmu i nazizmu, bliską współpracę z Führerem, a nawet pomoc w podporządkowaniu narodu niemieckiego totalitarnemu reżimowi. Jeden z publicystów nazwał papieża wręcz „ojcem chrzestnym i duchowym” ideologii nazistowskiej oraz „starym i wypróbowanym przyjacielem i sojusznikiem Hitlera" "'3. Zwracano uwagę, że w 1933 roku - jako sekretarz stanu Stolicy Apostolskiej - kardynał Pacelli doprowadził do zawarcia konkordatu z III Rzeszą oraz miał nie reagować na działalność katolików i organizacji kościelnych, które rzekomo głosiły faszystowskie poglądy. W prasie i publikacjach książkowych podkreślano, jakoby wybór hierarchy na papieża został przyjęty z zadowoleniem przez władze Włoch i Niemiec, a pierwszą głową państwa, którą Pius XII poinformował o swojej elekcji, był sam Adolf Hitler. Komunistyczni autorzy chętnie

11 W tym miejscu należy tylko wspomnieć, że komuniści wykorzystywali także inne narzędzia propagandowe, o których milczały analizowane źródła, m.in. audycje radiowe, magazyny filmowe Polskiej Kroniki Filmowej oraz karykatury prezentowane podczas wystaw karykatury politycznej.

12 A. Wołczyn, Niektóre aspekty polityki Watykanu, „Argumenty” 1958, 15-30 kwietnia, nr 7, s. 3.

13 J. Sikora, op. cit., s. 56, 117. 
przypominali, że nowy biskup Rzymu nazywany był w kołach watykańskich „Il Tedesco": papież-Niemiec. Donoszono także, że Pius XII rzekomo wspierał „faszystowskie" rządy generała Francisca Franco w Hiszpanii oraz Antónia de Oliveiry Salazara w Portugalii. Pacellemu wytykano, że rozpoczął swoje urzędowanie od wysłania gorących gratulacji temu pierwszemu z racji zwycięstwa nad republikanami w dopiero co zakończonej wojnie domowej. Propagandziści donosili, że Pius XII określił generała Franco mianem „chluby Kościoła katolickiego”, a stworzony przez niego system scharakteryzował jako „ostoję wiary katolickiej”"14.

Biskup Rzymu miał akceptować politykę „,ugłaskania” III Rzeszy oraz nie zareagować na zajęcie przez nią Czechosłowacji w 1939 roku. Propagandziści podkreślali, że Pacelli powstrzymał się od jednoznacznych kroków, które mogłyby zahamować wojenne plany nazistów, a tuż przed wybuchem światowego konfliktu dalej uważał, że należy prowadzić politykę ustępstw wobec Hitlera, nawet kosztem Polski. Dlatego też pragnął rzekomo, aby władze II Rzeczpospolitej spełniły żądania Berlina w sprawie Gdańska. W encyklice Summi Pontificatus z 20 października 1939 roku Pius XII miał uznać wojnę za „walkę interesów o sprawiedliwy rozdział bogactw, którymi Bóg obdarzył ludzi”, przez co rzekomo stał się „rzecznikiem i pomocnikiem” Lebensraum $^{15}$. Papieżowi zarzucano albo milczenie i zaniechanie reakcji, albo aktywne poparcie dla wojennych planów i zbrodni nazistów, noszące znamiona dobrowolnej kolaboracji. Zdaniem propagandzistów biskup Rzymu zaakceptował zajęcie ziem polskich przez Niemców, nie okazywał empatii wobec cierpiących Polaków oraz nie reagował na krzywdy zadawane ludności nad Wisłą. Zamiast tego w pierwszych latach II wojny światowej dążył rzekomo do kompromisowego pokoju, który umocniłby władzę Hitlera i oznaczał koniec polskiej państwowości. Pacelli popierał jakoby ideę „krucjaty” przeciwko komunizmowi i ZSRR, która miała być prowadzona pod przewodnictwem nazistowskich Niemiec. Podkreślano ponadto, że papież rzekomo nie chciał uznać walki z III Rzeszą za wojnę sprawiedliwą oraz pośrednio potępiał ruch oporu w okupowanych krajach Europy. Równocześnie miał wspierać państwa i organizacje kolaborujące z Niemcami, np. Słowację, Japonię oraz ukraińskich banderowców. Publicyści donosili o rzekomym przyjmowaniu niemieckich żołnierzy przez Piusa XII na specjalnych audiencjach w czasie wojny. Papież miał też otoczyć się kapłanami posiadającymi jakoby faszystowskie poglądy oraz często obdarzać ich godnościami kościelnymi - tak jak w przypadku watykańskiego urzędnika biskupa Aloisa Hudala, arcybiskupa Nowego Jorku Francisa Spellmana i biskupa gdańskiego Karla Marii Spletta.

Większość komunistycznych autorów podkreślała często, że Pius XII milczał wobec wojennych zbrodni: funkcjonowania obozów koncentracyjnych, rzezi jeńców, nalotów na miasta Polski i ZSRR oraz niemieckiej akcji burzenia i palenia Warszawy po upadku powstania w 1944 roku. Jeden z publicystów policzył, że w czasie wojny Pius XII zabrał głos na temat Polski 34 razy, nigdy nie posługując się takimi słowami,

14 K. Piwarski, Watykan a faszyzm (1929-1939) [w:] Szkice z dziejów papiestwa, red. K. Piwarski, Warszawa 1958, s. 418; M.M. Scheinman, Krótki zarys historii papiestwa, Warszawa 1954, s. 159.

15 J. Sikora, op. cit., s. 57. 
jak: Niemcy, Hitler, hitleryzm, faszyzm, krzywda, napastnik i zbrodnia ${ }^{16}$. Inny z autorów stwierdził, że biskup Rzymu poprzez swoje przemówienia wręcz „przygotowywał świat do uznania «hitlerowskiego ładu»" "17; ponadto zamiast piętnować okrucieństwa, głosił nauki o rodzinie, moralności i wychowaniu. Propagandziści w ogóle nie poruszali kwestii stosunku Piusa XII do Holocaustu. Wysnuwano jednak wnioski, że konsekwencją braku potępienia przez Pacellego zbrodni hitlerowskich w czasie wojny jest adekwatne milczenie wobec pogromów Żydów oraz mordowania milicjantów przez członków polskiego podziemia niepodległościowego po jej zakończeniu. Rzekomą papieską bierność wobec ideologii i bestialstwa nazistów często zestawiano z dekretem Świętego Oficjum z 1 lipca 1949 roku, wskazując na zadziwiający brak proporcji w stosowaniu słów potępienia pod adresem faszystów i komunistów. Jeden z felietonistów, nawiązując do ataku III Rzeszy na Polskę we wrześniu 1939 roku, pisał: „Grom klątwy nie padał wówczas z watykańskiego wzgórza, mimo że Hitler i czołowi przywódcy faszyzmu niemieckiego, jak Goebbels, Goering, Ribbentrop i Hi[m]mler byli katolikami, podlegającymi formalnie duchowej władzy Piusa XII"18. Równocześnie deprecjonowano wszelkie próby obrony biskupa Rzymu, które kwitowano stwierdzeniem, że ,uporczywe robienie z Piusa XII wroga Hitlera wygląda trochę na zabieg denazyfikacyjny" 19 .

Po zakończeniu światowego konfliktu Pius XII miał deklarować pomoc dla zbrodniarzy wojennych ze strony Kościoła, a także błogosławić i apelować o wielkoduszność dla nazistowskich oprawców. Donoszono, że papież prosił o ułaskawienie 200 hitlerowców, w tym Hansa Franka i Arthura Greisera; bronił, pobłogosławił i złożył życzenia Ernstowi von Weizsäckerowi, a także udzielił błogosławieństwa Oswaldowi Pohlowi. Po ogłoszeniu treści listu biskupa Rzymu do biskupów niemieckich z 1 marca 1948 roku jeden z publicystów uznał, że być może był on wskazówką dla niemieckich spowiedników, by w dalszym ciągu wielkodusznie rozgrzeszali faszystowskich katów ${ }^{20}$.

Propagandziści niezwykle często zwracali uwagę na wrogie stanowisko papieża wobec komunizmu jako ideologii i systemu politycznego. Uważano wręcz, że Pius XII dąży do jego zniszczenia, o czym miał świadczyć m.in. dekret Świętego Oficjum z 1 lipca 1949 roku. Zdaniem komunistycznych polityków i publicystów stanowił on akt polityczny, a nie religijny, groził ekskomuniką aż 1/3 ludzkości oraz dyskryminował „postępowych” wiernych. Podkreślano, że dokument zaakceptowany przez papieża powstał rzekomo z inicjatywy amerykańskich władz, podsyca zimną wojnę oraz ma na celu wywołanie rozruchów w krajach za żelazną kurtyną. Propagandziści pisali, że klątwa - „zacofana broń średniowiecza”21 - jest wymierzona w prostych ludzi, tworzy podziały w katolickich rodzinach oraz uderza w Polaków, którzy odbu-

16 Ibidem, s. 56.

17 S. Krasowski, op. cit., s. 31.

18 J. Szeląg [Z. Mitzner], Glos Watykanu i Glos Polski, „Przyjaciółka” 1949, 7 sierpnia, nr 32, s. 5 .

19 E. Ligocki, op. cit., s. 60.

20 Ibidem, s. 18.

${ }^{21}$ Klątwy, klątwy..., „Głos Wolnych” 1949, kwiecień, nr 4, s. 11. 
dowują kraj z wojennych zniszczeń. Ostracyzm Piusa XII wobec komunistów miał mieć wręcz tragiczne konsekwencje dla życia publicznego. W czasie procesu wolbromskiej Armii Podziemnej, w styczniu 1951 roku, stwierdzono, że Watykan poprzez swój stosunek do zwolenników ideologii marksistowskiej sugerował, że należy ich mordować. W jednym z artykułów pisano: „Pius XII nie zlecił zabijania komunistów. Wyklął ich tylko. [...] Ks. Oborski nie powiedział «zabijcie Grabińskiego». Dał tylko do zrozumienia, że trzeba tak zrobić" ${ }^{22}$. Informowano także, że papież wspiera jakoby działalność szpiegowską duchownych w państwach „demokracji ludowej”, głównie na rzecz USA. Pacelli miał ponadto prowadzić w Rzymie wyższą uczelnię wywiadowczą - Collegium Russicum.

Wielokrotnie podkreślano zresztą, że Pius XII popiera „,anglo-amerykański imperializm”, który rzekomo kontynuował „misję dziejową hitleryzmu”, stając się przez to atrakcyjnym dla Stolicy Apostolskiej ${ }^{23}$. Propagandziści często przytaczali słowa z listu papieża do prezydenta Harry'ego Trumana z 26 sierpnia 1947 roku: „Nikt bardziej niż My nie życzy Waszej Ekscelencji sukcesu, a dla pomyślnego osiągnięcia Pańskiego celu stawiamy Panu do dyspozycji Nasze środki i gorąco błagamy Boga o pomoc..."24. Urosły one do rangi symbolu afirmacji polityki Stanów Zjednoczonych przez Watykan, mimo że - jak podkreślano - prezydenci USA wyznawali protestantyzm. Biskup Rzymu miał być nawet skłonny za określone sumy dolarów udzielić równoczesnego wsparcia dwóm kandydatom do Białego Domu, reprezentującym zarówno republikanów, jak i demokratów. Na określenie powojennych relacji pomiędzy Stanami Zjednoczonymi a Stolicą Apostolską w publicystyce niejednokrotnie używano określenia „oś W-W”, czyli „oś Waszyngton-Watykan” (lub Wall Street-Watykan), czy nawet „oś W-W-W”: Waszyngton-Watykan-Wojna. Propagandziści zwracali uwagę na częste przyjmowanie na audiencjach i błogosławienie przez Piusa XII amerykańskim ministrom, parlamentarzystom, finansistom i wojskowym, którzy mieli wywierać wpływ na treść wystąpień papieża. Jeden z publicystów wyliczył na podstawie kroniki papieskich audiencji z pisma „L'Osservatore Romano", że w samym roku 1951 Pacelli podejmował przybyszów zza Atlantyku niemal codziennie, a ok. 200 razy gościł u siebie przedstawicieli amerykańskich sił zbrojnych $^{25}$. Donoszono, że „papież Stanów” popiera doktrynę Trumana, a także plan Marshalla, którego celem było jakoby polityczne i gospodarcze „zwasalizowanie” Europy Zachodniej przez USA. Pius XII miał także nakazać europejskim hierarchom bezwarunkową akceptację działań Waszyngtonu.

$\mathrm{W}$ propagandowych pracach rozpisywano się o bliskich relacjach papieża z zachodnioeuropejskimi politykami. Pius XII miał przyjmować na audiencjach, błogosławić i obdarzać odznaczeniami przywódców i wysokich dostojników z Francji, Niemiec Zachodnich, Włoch, Grecji, Hiszpanii czy Belgii. Donoszono o wyraźnym

22 M.L. Bielicki, Dwie czy jedna moralność Oborskich?, „Żołnierz Wolności” 1951, 18 stycznia, nr 18 , s. 3.

23 A. Nowicki, Watykan na stużbie Wall-Street, „Polska Zbrojna” 1949, 12 marca, nr 69, s. 4.

${ }^{24}$ Idem, Papież Pius XII w świetle..., s. 68; A. Klominek, Ze starych i nowych kronik, „Przekrój” 1951, 4 marca, nr 308, s. 9; S. Krasowski, op. cit., s. 5.

25 A. Nowicki, Papież Pius XII w świetle..., s. 66-68. 
politycznym zaangażowaniu Pacellego, np. o rzekomych wspólnych rozmowach z Konradem Adenauerem, Alcide De Gasperim i Myronem Taylorem (amerykańskim przedstawicielem przy Stolicy Apostolskiej) w sprawie utworzenia sojuszu RzymParyż-Bonn, do którego miał dołączyć też Madryt. Pius XII rzekomo wyświadczał wydatne przysługi włoskiej chadecji - np. zezwalając, by w dniu wyborów zakonnice wyszły za klauzurę w celu oddania głosu na partię De Gasperiego. Propagandziści zwracali uwagę na poparcie papieża dla procesu integracji europejskiej, pod którego przykrywką miała jakoby następować odbudowa niemieckiego imperializmu. Pacellego oskarżano ponadto o polityczne zaangażowanie na Dalekim Wschodzie, utrzymywanie serdecznych relacji z japońskim cesarzem Hirohito oraz udzielenie wsparcia chińskiej partii Kuomintang.

Pius XII określany był niezwykle często mianem ,podżegacza wojennego”. Uważano, że sprzyja „polityce antypoczdamskiej” oraz podburza do wybuchu III wojny światowej, licząc na pokonanie ZSRR i opanowanie przez ,imperialistów” całego świata. Propagandziści utrzymywali, że Pacelli za podjudzanie do konfliktu otrzymywał pieniądze od władz USA. Pisano wręcz, że ,piastuje on dwa stanowiska, papieża i urzędowego podżegacza wojennego"26. Biskup Rzymu poparł jakoby powstanie i działalność Organizacji Paktu Północnoatlantyckiego (NATO), a także pragnął stworzenia wspólnego frontu osób wierzących przeciwko materializmowi i komunizmowi. „Papieżowi atlantyckiemu” ${ }^{27}$ czyniono wyrzuty za to, że rzekomo nie potępia konfliktów zbrojnych z udziałem Amerykanów na Dalekim Wschodzie oraz wspiera militarną politykę państw zachodnich. Donoszono także, że Pacelli krytykuje postulaty rozbrojenia oraz sprzeciwia się ruchowi światowego pokoju, o czym miał świadczyć choćby brak poparcia dla Apelu Sztokholmskiego ${ }^{28}$ czy ekskomunikowanie aktywnego działacza Komitetu Obrońców Pokoju księdza Jeana Bouliera. Pius XII rzekomo wypowiadał się też pozytywnie o broni jądrowej (nazywając bombę atomową „orężem Pana Boga”) - ale do czasu, gdy okazało się, że posiadają ją nie tylko Amerykanie, ale także Sowieci.

Według propagandzistów Pacelli popierał kapitalizm, uważając go za system gospodarczy wyrażający porządek ustanowiony przez Boga. Pius XII miał wręcz uczynić z Watykanu ideologiczne narzędzie obozu kapitalistycznego. W związku z tym drwiono, że „papież nie potrzebuje się obawiać porażenia słonecznego, gdyż stale znajduje się w cieniu dolara" 29 . Publicyści utrzymywali, że jako sekretarz stanu Pacelli silnie związał Stolicę Apostolską z amerykańskim przedsiębiorstwem finansowym miliardera Henry'ego S. Morgana, a jako papież pomógł w podporządkowaniu włoskiej gospodarki kapitałowi zza Atlantyku. Dlatego też kpiono, że „głowa kościoła [sic!] przyjmuje komunię w postaci papierów wartościowych, a błogosławieństwa

26 Watykan wobec groźby pokoju. „, Da pacem, Domine”, „Głos Wolnych” 1950, 15 lipca, nr 13, s. 4.

27 A. Nowicki, Pius Atlantycki (1), „Polska Zbrojna” 1949, 1 kwietnia, nr 89, s. 4.

28 Apel Sztokholmski, zaprezentowany z inicjatywy komunistycznej Światowej Rady Pokoju 25 marca 1950 r., wzywał narody do przeprowadzenia plebiscytu w sprawie zakazu produkcji broni atomowej. W tym celu zorganizowano akcje zbierania podpisów na szeroką skalę, zwłaszcza w krajach za żelazną kurtyną.

29 Drobiazgi, „Mucha” 1949, 14 sierpnia, nr 33, s. 6. 
udziela mu Morgan, na którego spłynęła łaska nieomylności i wszechpotęgi" ${ }^{30}$. Pius XII rzekomo wychwalał funkcje banków i obieg waluty, a Rok Święty 1950 ustanowił w celu wzbogacenia się kosztem naiwnych pielgrzymów. Pacelli miał zresztą pragnąć, aby Watykan znacznie pomnożył swój majątek. Za jego pontyfikatu Państwo Kościelne posiadało rzekomo wielomiliardowe kapitały oraz nadzór ze strony zasiadających w radach nadzorczych świeckich katolików w ogromnej liczbie banków, koncernów, przedsiębiorstw i spółek akcyjnych we Włoszech i na całym świecie. Publicyści chętnie podawali wartości zdeponowanych przez Watykan zapasów złota czy posiadanych nieruchomości, sięgające kilku miliardów dolarów. „Bankierowi w tiarze" 31 zarzucano równocześnie nepotyzm, gdyż jego trzej bratankowie mieli zostać szefami lub członkami rad nadzorczych ogromnej liczby ważnych włoskich przedsiębiorstw i spółek akcyjnych. Donoszono także, że mężczyźni prowadzili sprawy finansowe Stolicy Apostolskiej, dokonując spekulacji na giełdzie i rynku nieruchomości. Propagandziści utrzymywali, że Pius XII sam powiązany jest z aferami finansowymi w Watykanie; przykładowo miał przymykać oko na przestępczą działalność kamerdynera papieskiego, księdza Edoarda Prettnera Cippico, oskarżonego m.in. o wielomilionowe oszustwa, przestępczy handel walutami ze szkodą dla włoskiej gospodarki, przyjmowanie łapówek, szmuglowanie złota i brylantów oraz kradzież klejnotów.

W antypapieskich publikacjach często podkreślano, że Pius XII zajmuje wrogie stanowisko wobec socjalizmu, rozumianego nie tylko jako doktryna polityczna, ale także gospodarcza. Papież rzekomo potępiał upaństwowienie gospodarki i środków produkcji oraz uspołecznienie handlu, broniąc za to inicjatywy prywatnej. Propagandziści utrzymywali, że Pacelli jest wrogiem robotników i chłopów. „Ludzi pracy” oskarżał jakoby o wygórowane wymagania i potrzeby; w jednym z przemówień miał skarcić ich „za domaganie się okrasy do ziemniaków, karmelka dla dzieciaka czy też może książki zamiast modlitewnika"32. Pacelli sprzeciwiał się rzekomo próbom zmian stosunków własnościowych przez chłopów, reformie rolnej i mechanizacji wsi. Pius XII miał też pragnąć podtrzymania nierówności społecznych, głosić ich nieprzemijający charakter, potępiać walkę o prawa pracownicze oraz wspierać kapitalistycznych wyzyskiwaczy. Propaganda głosiła, że - jako głowa Państwa Watykańskiego - papież jest jednym z największych posiadaczy ziemskich w Italii, który ponosi współodpowiedzialność za brak ziemi i mieszkań dla milionów najuboższych Włochów. Ich trudną sytuację materialną zestawiano $\mathrm{z}$ - jak pisano - nieprzyzwoitym, sprzecznym z ewangelicznymi zasadami bogactwem Watykanu, w którym mieszkał i sprawował władzę Pacelli. Biskupowi Rzymu zarzucano, że nie kieruje się w swym życiu takimi wartościami, jak skromne życie, pogarda wobec dóbr doczesnych i wspieranie ubogich.

Papieża bardzo często oskarżano o antypolonizm, germanofilstwo oraz sprzyjanie niemieckiemu rewizjonizmowi po II wojnie światowej. Pius XII rzekomo nie uznawał

30 D.I. Zasławski, Filozoficzne majaczenia watykańskich jezuitów, „Myśl Filozoficzna” 1953, nr 4, s. 288.

31 T. Polanowski, Schacht $w$ Watykanie, „Mucha” 1952, 21 grudnia, nr 51, s. 5.

32 W. Polkow ski, Czciciele złota, „Głos Wolnych” 1949, kwiecień, nr 4, s. 19. 
powojennej granicy na Odrze i Nysie Łużyckiej, pragnął jej zmiany oraz opowiadał się za powrotem tzw. Ziem Odzyskanych do Niemiec. O poglądach Pacellego miały świadczyć jego liczne wystąpienia, ale przede wszystkim list do biskupów niemieckich z 1 marca 1948 roku. W reakcji na dokument pisano: „Gdy Hitler przesuwał granice Reichu na wschód, papież nie protestował. Gdy Polska sięgnęła nad Odrę i Nysę - załamał ręce" ${ }^{\text {33 }}$. Równocześnie prasa podkreślała, że po ogłoszeniu treści listu nad Renem nastąpił wzrost nastrojów rewizjonistycznych i nacjonalistycznych. Zwracano uwagę również na inne gesty Pacellego lub też na - jak utrzymywano - wymowną bierność papieża. Przykładowo Pius XII miał nie zareagować na specjalny memoriał Związku Polaków w Niemczech z 1948 roku, którego celem było zwrócenie uwagi biskupa Rzymu i niemieckich hierarchów na rzekomo antypolską działalność części tamtejszego duchowieństwa. Gwałtownej krytyki doczekało się także radiowe przemówienie do berlińczyków z 17 lipca 1949 roku, wygłoszone przez papieża w języku niemieckim. Pacellemu zarzucano równocześnie wspieranie działalności władz Niemiec Zachodnich, w tym przede wszystkim kanclerza Adenauera. Podkreślano, że Pius XII chętnie przyjmuje niemieckie pielgrzymki oraz odznacza polityków i wojskowych z Bonn. Przyjazna postawa wobec Niemiec miała kontrastować z niby negatywnym stosunkiem biskupa Rzymu wobec Polski. Jego świadectwem miała być nie tylko postawa Pacellego w czasie II wojny światowej, ale także po jej zakończeniu, gdy papież oskarżał komunistyczne władze - jakoby posługując się kłamstwem - o prześladowanie Kościoła nad Wisłą. Działalność Piusa XII przedstawiano jako logiczną kontynuację rzekomo antypolskiej polityki Stolicy Apostolskiej na przestrzeni wieków.

W propagandowych pracach papież jawi się jako wróg nauki, który posługuje się nią w instrumentalny sposób. Propagandziści albo podkreślali, że Pacelli jest całkowicie krytyczny wobec teorii ewolucji oraz poglądów „konkordystów” (usiłujących godzić ewolucjonizm z wiarą katolicką), albo zwracali uwagę, że odrzuca on jedynie koncepcję poligenizmu ${ }^{34}$ odnośnie do pochodzenia człowieka, wypaczając przy tym teorię Karola Darwina. Potępienie poligenizmu - jako sprzecznego z Biblią - miało świadczyć o podważaniu przez biskupa Rzymu tez nauki niezgodnych z prawdami wiary. Piusowi XII zarzucano zresztą, że wybiórczo dobiera naukowe fakty i hipotezy w ten sposób, by pasowały do jego fideistycznych koncepcji, przy równoczesnym przemilczaniu niewygodnych dla niego ustaleń badaczy.

Pacellego przedstawiano także jako zacofanego konserwatystę w kwestiach dotyczących wiary i moralności. Papież miał krytykować przeciwników tomizmu, określających ów system jako przestarzały, a także podkreślać fakt, że obowiązuje on również współczesnych ludzi. Postawa ta świadczyła rzekomo o uporze biskupa Rzymu, by tkwić przy średniowiecznych, przestarzałych teoriach. Nowe wydanie Indeksu ksiag zakazanych, ogłoszone w czasie pontyfikatu Pacellego w 1948 roku (a będące zarazem ostatnią edycją wykazu w dziejach), zostało uznane za znak

\footnotetext{
33 E. Ligocki, op. cit., s. 43.

34 Poligenizm zakłada, że rodzaj ludzki wywodzi się od wielu par przodków.
} 
kontynuowania przez Watykan „,inkwizycyjnych tradycji”" ${ }^{35}$. Z dezaprobatą wyrażano się na temat ogłoszenia przez Piusa XII w 1950 roku dogmatu o Wniebowzięciu Matki Bożej, który - jak pisano - „stworzy z trójcy [sic!] i tak już poplątanej i zawiłej, czteroosobowość pojęcia" oraz oddali wizję zbliżenia protestantów do Rzymu ${ }^{36}$. Zwracano także uwagę, że papież autorytarnie uzasadnia prawdziwość objawień maryjnych w Fatimie z 1917 roku oraz własnych obserwacji rzekomego cudu „tańca słońca" w Ogrodach Watykańskich przez trzy kolejne jesienne wieczory roku 1950. Celem tego zabiegu miało być jakoby utwierdzenie niewykształconych portugalskich chłopów w wierności wobec bliskiego Kościołowi Salazara. Donoszono także, że watykańska drukarnia poufnie wydrukowała kilka egzemplarzy opisów objawień prywatnych Pacellego i sprzedała je za wiele milionów lirów, pod warunkiem zachowania tajemnicy za życia papieża; sekret wyszedł jednak na jaw. Jeden z redaktorów snuł wnioski: „Pius XII był na łożu śmierci. Aby otrzymać wysoką, choć pośmiertną rangę świętego trzeba mieć za sobą trzy widzenia. Nic więc dziwnego, że złożony chorobą papież starał się pospiesznie wykonać plan w tej dziedzinie" ${ }^{37}$. Pacellemu zarzucano „reakcjonizm” w kwestiach wiary i moralności, ale także doktrynalną elastyczność, w zależności od tego, do kogo kierował swoje nauki. Przykładowo papież miał nakłaniać włoskich proboszczów do surowego nauczania o piekle, z kolei do katolickich uczonych wygłosić „przemówienie pełne «intelektualnej i naukowej» kokieterii" ${ }^{38}$.

Warto dodać, że komunistyczni publicyści poruszali nawet zagadnienia dotyczące czysto prywatnych, czy wręcz intymnych spraw papieża. Donoszono przykładowo, że Pius XII z przyczyn zdrowotnych musi zwiększyć dzienną porcję spożywanego białego wina $\mathrm{z} 3 / 4$ litra do 1 litra i więcej. W związku z tym redaktorzy pisali: „Żywimy poważne obawy, iż papież może stać się ofiarą bardzo brzydkiego nałogu", pytając szyderczo, czy wina nie można zastąpić coca-coląa ${ }^{39}$. Posługując się niedomówieniami, informowali także o rzekomo zbyt bliskich związkach Pacellego z siostrą Pascaliną Lehnert. Niemiecką zakonnicę określono jako „wierną opiekunkę i przyjaciółkę” Piusa XII, dodając, że „niektórzy niezbyt tolerancyjni komentatorzy nazywają ją «papieżową», ale to tylko przez zazdrość" ${ }^{40}$. W cudzysłów ujmowano termin „gospodyni”, sugerując, że siostra Pascalina jest dla biskupa Rzymu kimś więcej niż tylko opiekunką apartamentu w Pałacu Apostolskim ${ }^{41}$. Dodawano ponadto, że poufałość zakonnicy wobec Pacellego stanowi świadectwo, że „nikt tak jak ona nie zna papieża..."

35 J. Kuczyński, Urok wiary, „Po Prostu” 1955, 25 września, nr 30, s. 24.

36 T.K., ,Nieomylność” w opałach, ,Głos Wolnych” 1950, 15 października, nr 19, s. 3.

37 I.B., Cuda XX wieku, „Po Prostu” 1956, 8 stycznia, nr 2, s. 2.

38 J. Kuczyński, Urok..., s. 25.

39 bes, Wino życia, „Głos Wolnych” 1950, 1 kwietnia, nr 6, s. 4.

40 Mowa trawa: „Papieżowa”, „Po Prostu” 1957, 7 kwietnia, nr 14, s. 8.

${ }^{41}$ Ibidem.

42 H.K. [H. Kollat], Dlaczego kardynat Tisserant tak dlugo rozmawiat z papieżem?, „Sztandar Młodych" 1953, 21 kwietnia, nr 94, s. 6. 
$\mathrm{Z}$ analizowanych publikacji wyłania się obraz Piusa XII jako przebiegłego, chciwego i pozbawionego skrupułów przywódcy religijnego, który wykorzystuje Kościół do politycznych rozgrywek; wyrachowanego, niemoralnego i zakłamanego hipokryty, głoszącego ciemnotę i zabobon; ideologicznego przeciwnika społeczeństw dążących jakoby do zbudowania socjalizmu. Pacelli został tym samym umieszczony w gronie „obcych” i „wrogów ludu”. Równocześnie należy zaznaczyć, że autorzy antypapieskich książek i artykułów - w zależności od celu, jaki sobie stawiali - kładli nacisk na inne postawy i cechy charakteru Pacellego, niekiedy wzajemnie ze sobą sprzeczne. $Z$ jednej strony pisano bowiem o braku skrupułów, ostrości i wyniosłości Piusa XII, a z drugiej strony utrzymywano, że papież jest naiwny i labilny, ulega złudzeniom, podejmuje nietrafne decyzje oraz łatwo daje się wykorzystywać przez inne wpływowe osoby.

Jan Żaryn zauważył, że komunistyczna propaganda wymierzona w biskupa Rzymu posługiwała się nawet kalkami z kampanii organizowanych przez Goebbelsa ${ }^{43}$. Oprócz kłamstwa ważnym narzędziem antypapieskich propagandzistów stało się przemilczanie lub zatajanie niewygodnych informacji. Przykładowo nie podawano, że Pacelli był inicjatorem i współtwórcą antynazistowskiej encykliki Piusa XI Mit brennender Sorge oraz nigdy nie spotkał się z Hitlerem. Nie zająknięto się również o podziemnej, charytatywnej i dyplomatycznej pomocy papieża wobec ofiar II wojny światowej nad Wisłą i w całej Europie. Przez kilka tygodni Polacy nie mieli możliwości poznania oryginalnego brzmienia listu Piusa XII do biskupów niemieckich z 1 marca 1948 roku. Cenzura uniemożliwiła także zaznajomienie się z treścią jego listu do episkopatu polskiego z 1 września 1948 roku, poprzez który papież okazał solidarność z rodzimymi przesiedleńcami ze Wschodu ${ }^{44}$.

Równocześnie należy przyznać, że w procesie budowania negatywnego wizerunku Pacellego władze nad Wisłą miały częściowo ułatwione zadanie. Ostry antykomunizm Piusa XII, postawa bezstronności w czasie II wojny światowej, sympatia do niemieckiego narodu i kultury, nawoływanie do miłosierdzia dla zbrodniarzy wojennych, uznawanie zachodniej demokracji jako zapory przeciwko totalizmowi, oczekiwanie na powojenną konferencję pokojową, która ostatecznie usankcjonuje nowe granice europejskich państw - wszystkie te czynniki dawały niejako „paliwo” antypapieskiej propagandzie. Zarzuty padające pod adresem biskupa Rzymu nie zawsze zawierały same kłamstwa, lecz - w wyniku manipulacji i nieżyczliwych interpretacji - pomijały określony kontekst i nie oddawały właściwego sensu papieskich słów i gestów. Mimo wszystko należy przyznać, że Pacellego spotykała krytyka niemal za wszystko, co mówił lub (nie) robił; stan ten przerwałoby prawdopodobnie dopiero wystąpienie afirmujące komunistyczny system. Tragizm postaci Piusa XII - dostrzegalny nie tylko na podstawie badań jego współczesnych biografów, ale także w wyniku analizy antypapieskich działań propagandowych w Polsce Ludowej - polegał na

43 J. Żaryn, Pius XII wobec kwestii polskiej (1939-1945) - glos w dyskusji [w:] Pius XII. Papież w epoce totalitaryzmów..., s. 177.

44 B. Cywiński, op. cit., s. 51. 
staniu się ofiarą ówczesnej sytuacji międzynarodowej oraz uwarunkowań politycznych i społecznych, ale także własnych doświadczeń życiowych.

Marek Kornat stwierdził, że negatywny wizerunek Piusa XII należał do „swoistego kanonu «polityki historycznej» PRL"45. Jego zdaniem częste posługiwanie się kłamstwem przez propagandzistów uniemożliwiło merytoryczną dyskusję nad oceną pontyfikatu Pacellego. Uderzanie w biskupa Rzymu i Kościół doprowadziło bowiem katolickich publicystów do przyjęcia taktyki „obrony papieża za wszelką cenę" ${ }^{46}$. Można by dodać, że w rezultacie współczesne zarzuty kierowane pod adresem Pacellego - w znacznym stopniu pokrywające się z oskarżeniami formułowanymi w okresie stalinowskim - początkowo nie mogły zostać zestawione z obiektywną literaturą na jego temat. Dzisiaj, w dobie licznych ataków pod adresem Piusa XII - niekiedy równie kłamliwych, pełnych manipulacji i złej woli - warto pamiętać także o długiej metryce antypapieskiej nagonki.

\section{BIBLIOGRAFIA}

\section{a) Źródła drukowane}

Książki i artykuły w wydawnictwach zbiorowych

Bieńkowski W., Polityka Watykanu wobec Polski, Warszawa 1950.

Krasowski S., Watykan a Polska, Warszawa 1949.

Ligocki E., Między Watykanem a Polska, Warszawa 1949.

Nowicki A., 1000 lat zatargów z papieżami, Warszawa 1950.

Nowicki A., Papież Pius XII w świetle własnych przemówień i listów z lat 1945-1951, Warszawa 1952.

Piwarski K., Watykan a faszyzm (1929-1939) [w:] Szkice z dziejów papiestwa, red. K. Piwarski, Warszawa 1958.

Scheinman M.M., Krótki zarys historii papiestwa, Warszawa 1954.

Sikora J., Watykan czy Polska?, Warszawa 1950.

Warecki R. [Arski S.], Watykan i Wrzesień, Warszawa 1958.

\section{b) Artykuły prasowe}

bes, Wino życia, „Głos Wolnych” 1950, 1 kwietnia, nr 6.

Bielicki M.L., Dwie czy jedna moralność Oborskich?, „Żołnierz Wolności” 1951, 18 stycznia, nr 18.

Drobiazgi, „Mucha” 1949, 14 sierpnia, nr 33.

45 M. Kornat, Pius XII, totalitaryzm, II wojna światowa i Polska (rozważania historiograficzne) [w:] Pius XII. Papież w epoce totalitaryzmów..., s. 70.

46 Ibidem. 
H.K. [Kollat H.], Dlaczego kardynat Tisserant tak dtugo rozmawiał z papieżem?, „Sztandar Młodych" 1953, 21 kwietnia, nr 94.

I.B., Cuda XX wieku, „Po Prostu” 1956, 8 stycznia, nr 2.

Klątwy, klątwy..., „Głos Wolnych” 1949, kwiecień, nr 4.

Klominek A., Ze starych i nowych kronik, „Przekrój” 1951, 4 marca, nr 308.

Kuczyński J., Urok wiary, „Po Prostu” 1955, 25 września, nr 30.

Mowa trawa: „Papieżowa”, „Po Prostu” 1957, 7 kwietnia, nr 14.

Nowicki A., Pius Atlantycki (1), „Polska Zbrojna” 1949, 1 kwietnia, nr 89.

Nowicki A., Watykan na stużbie Wall-Street, „Polska Zbrojna” 1949, 12 marca, nr 69.

Polanowski T., Schacht w Watykanie, „Mucha” 1952, 21 grudnia, nr 51.

Polkowski W., Czciciele złota, „Głos Wolnych” 1949, kwiecień, nr 4.

Szeląg J. [Mitzner Z.], Głos Watykanu i Głos Polski, „Przyjaciółka” 1949, 7 sierpnia, nr 32.

T.K., ,Nieomylność” w opałach, ,Głos Wolnych” 1950, 15 października, nr 19.

Watykan wobec groźby pokoju. „Da pacem, Domine”, „Głos Wolnych” 1950, 15 lipca, nr 13. Wołczyn A., Niektóre aspekty polityki Watykanu, „Argumenty” 1958, 15-30 kwietnia, nr 7. Zasławski D.I., Filozoficzne majaczenia watykańskich jezuitów, „Myśl Filozoficzna” 1953, nr 4.

\section{c) Prace niepublikowane}

Nowak A., Propaganda antypapieska w Polsce w latach 1945-1956, Wrocław 2004 (praca doktorska napisana pod kierunkiem prof. dr. hab. J.K. Pietrzaka w Instytucie Historycznym Uniwersytetu Wrocławskiego).

Sanak M., Papież Pius XII w propagandzie komunistycznej w Polsce w latach 1945-1958, Kraków 2016 (praca magisterska napisana pod kierunkiem dr. hab. Z. Zblewskiego w Instytucie Historii Uniwersytetu Jagiellońskiego).

\section{d) Opracowania}

Cywiński B., Ogniem próbowane. Z dziejów najnowszych Kościoła katolickiego w Europie Środkowo-Wschodniej, t. 2: „, .. i was prześladować będa”, Warszawa 1994.

Dudek A., Państwo i Kościót w Polsce w latach 1945-1970, Kraków 1995.

Dziurok A., Kruchtoizacja. Polityka władz partyjno-państwowych wobec Kościoła katolickiego w latach 1945-1956 w województwie śląsim/katowickim, Katowice 2012.

Gryz R., Państwo a Kościót w Polsce 1945-1956. Na przykładzie województwa kieleckiego, Kraków 1999.

Jurkiewicz W., Antykościelna propaganda na lamach miesięcznika „Wiedza i Życie” $w$ latach 1950-1956 [w:] Propaganda antykościelna $w$ Polsce $w$ latach 1945-1978, red. S. Dąbrowski, B. Rogowska, Wrocław 2001.

Kamiński Ł., Antykościelna kampania propagandowa na Dolnym Ślasku w 1949 r. (po ekskomunice członków partii marksistowskiej) [w:] Propaganda antykościelna $w$ Polsce w latach 1945-1978, red. S. Dąbrowski, B. Rogowska, Wrocław 2001.

Kornat M., Pius XII, totalitaryzm, II wojna światowa i Polska (rozważania historiograficzne) [w:] Pius XII. Papież w epoce totalitaryzmów. Historiografia i polityka, red. M. Kornat, Kraków 2010. 
Kucharczyk G., Obraz pontyfikatu Piusa XII w prasie polskiej (w Kraju i na emigracji po 1945 r.). Próba zarysu [w:] Pius XII. Papież w epoce totalitaryzmów. Historiografia i polityka, red. M. Kornat, Kraków 2010.

Ordyłowski M., Polityka lokalnych władz PRL wobec Kościoła katolickiego na Dolnym Ślasku w latach 1945-1979 [w:] Stefan kardynat Wyszyński wobec Ziem Zachodnich i Pótnocnych oraz stosunków polsko-niemieckich. W 100-lecie urodzin Prymasa Tysiąclecia, red. T. Dzwonkowski, Cz. Osękowski, Warszawa-Poznań-Zielona Góra 2001.

Sikorski J., Władza a Kościół na Ziemi Lubuskiej w latach 1945-1956, „Rocznik Lubuski” 2005, t. 31, cz. 2.

Stefaniak J., Polityka władz państwowych PRL wobec prasy katolickiej w latach 19451953, Lublin 1998.

Wójtowicz N., Walka o „,kulturę świecka” w pracach pierwszego przewodniczacego Stowarzyszenia Ateistów $i$ Wolnomyślicieli [w:] Propaganda antykościelna $w$ Polsce $w$ latach 1945-1978, red. S. Dąbrowski, B. Rogowska, Wrocław 2001.

Zieliński Z., Pius XII. Historiografia zaangażowana [w:] Pius XII. Papież w epoce totalitaryzmów. Historiografia i polityka, red. M. Kornat, Kraków 2010.

Żaryn J., Kościól a władza w Polsce (1945-1950), Warszawa 1997.

Żaryn J., Pius XII wobec kwestii polskiej (1939-1945) - głos w dyskusji [w:] Pius XII. Papież w epoce totalitaryzmów. Historiografia i polityka, red. M. Kornat, Kraków 2010. 